\title{
Article \\ Factors Influencing the Extent of the Ethical Codes: Evidence from Slovakia
}

\author{
Jana Kozáková *DiD, Mária Urbánová and Radovan Savov \\ Faculty of Economics and Management, Slovak University of Agriculture in Nitra, Tr. A. Hlinku 2, \\ 94976 Nitra, Slovakia; maria.urbanova1@uniag.sk (M.U.); radovan.savov@uniag.sk (R.S.) \\ * Correspondence: jana.kozakova@uniag.sk; Tel.: +42-376-414-130
}

check for

updates

Citation: Kozáková, Jana, Mária Urbánová, and Radovan Savov. 2021. Factors Influencing the Extent of the Ethical Codes: Evidence from

Slovakia. Journal of Risk and Financial Management 14: 40. https://doi.org/ 10.3390/jrfm14010040

Received: 30 November 2020

Accepted: 14 January 2021

Published: 17 January 2021

Publisher's Note: MDPI stays neutral with regard to jurisdictional claims in published maps and institutional affiliations.

Copyright: (c) 2021 by the authors. Licensee MDPI, Basel, Switzerland. This article is an open access article distributed under the terms and conditions of the Creative Commons Attribution (CC BY) license (https:// creativecommons.org/licenses/by/ $4.0 /)$.

\begin{abstract}
Even though formalization of ethical principles is a must in today's business, research and evidence in the Slovak conditions remain scarce. Yet, creating an ethical business climate and especially the formalization of ethics through codes of ethics incorporated in corporate standards is a particularly interesting phenomenon in the conditions of transit economies due to the significant role of multinationals in this process. Therefore, the purpose of this study was to examine main factors influencing the extent of ethical codes in 225 subsidiaries of multinational companies operating in Slovakia. The conducted questionnaire study containing items focused on area and extent of ethical code, number of employees, economic performance, regional and industrial scope, ownership structure, and nationality of executive director was used as a tool for data collection. Factor analysis was processed to identify the interdependencies between observed variables and to find the latent variables. Further, the Kruskal-Wallis test was applied to identify the differences among the variables along with the Bonferroni correction test, which specified the items between which the significant difference occurred. The following findings emerged. First, companies with lower extent of ethical code use general phrases. When they want to specialize on any ethics problems, extent must be wider. Second, companies with a lower number of employees do not need extensive ethical code due to clear rules with which they are familiar in a direct way by owners. In multinational companies, the communication of ethical rules is realized via ethical codes with specific purposes because the direct way is impossible. Third, companies with foreign ownership used different managerial approaches, and therefore ethical codes differ in extent and content.
\end{abstract}

Keywords: corporate code of ethics; extent of code; content of ethical code; ownership structure; company size

\section{Introduction}

The importance of constructing the positive organizational climate was highlighted decades ago. Back in the 1970s, Schneider (1975) defined climate in an organization as perceptions of organizational practices and procedures shared among members. Even though there are diverse types of climates in the workplace, the one related to the established normative systems of organization was considered ethical climate (Martin and Cullen 2006), which also reflects the organizational procedures, polices, and practices with moral consequences. The idea of ethical climate was developed by Victor and Cullen (1988), who added that it identifies the normative systems that guide organizational decision-making and the systematic responses to ethical dilemmas. Authors also defined ethical climate as the prevailing perceptions of typical organizational practices and procedures with ethical content. Cullen et al. (1989) enlarged that, as such, an ethical climate is an essential element of the organizational culture.

Society considers that every individual knows what it means to be ethical: to know right from wrong and to know when you are practicing one instead of the other, but acting ethically in business means more than simply observing relevant laws and regulations 
(Skripak 2016). As businesses interact with society, a shared interest and interdependence develop between the company and stakeholders (Freeman 2010), and when organizations gain public respect and community approval, they have accomplished far more than making a return on their investment (Brady 1999). The public is becoming more concerned about what is really happening in business organizations in the name of competition, growth, and profitability (Jalil et al. 2010), and since stakeholder power has become increasingly important (Weinstein 2012), ethics and values have become critical success factors of business (Twomey and Jennings 2011). Therefore, proper implementation of business ethics in organizations can ensure maximization of lawful profits and effectively protect the interests of all stakeholders (Machan 2009).

The ethical behavior of an organization can be stated through realization of various activities. Axelrod (2004) concluded that most lists of ethical organizational activities include the criteria of treating stakeholders fairly, communicating core values and principles to all employees, holding them personally accountable for their actions and demanding (rewarding) their integrity in all situations. To prevent problems, corporate leaders should ensure that their companies behave in an ethical manner and do what is right for all stakeholders (Bassell et al. 2015). However, this purpose of ethics and morality is, in many ways, in conflict with the core purpose of business itself, which is commonly known as "business ethics oxymoron" (Kelly 2002). If reaching ever-increasing profit is the basic drive and principle of business, and economic profitability is the primary and prevailing factor in strategic business decisions, ethics and business eventually must conflict (Duska 2000). On the other hand, no one should criticize companies for wanting to maximize their return on investment and to ensure their longevity. However, they should stay ethical in the process because it is the right thing to do, and not just because such action will be the "right" thing for the business (Wood 2002).

The principles of business ethics were presented to Europe and Japan in the 1980s, despite the problems with the translation of the term in many languages and various developments of the concept in each country regarding their socio-political-economic differences with a diverse local emphasis and history (De George 2005). In the 1990s, a wave of voluntary organizational codes appeared, activated by effort for an improved reputation and to distance companies from unethical practices and scandals (Van Tulder and Kolk 2001). An increasing number of entities started to incorporate codes to voluntarily commit themselves to ethical norms and values. Business initiatives interacted with the continued effort of international organizations, governments, and social interest groups, resulting in a veritable "cascade of codes", stated Organization for Economic Co-operation and Development (OECD 1999) in 1999.

Globalization with the global business market and modern technologies have provided many opportunities for companies, but also brought some risk that is not fully realized. Ethics is very closely linked to this risk because ethical considerations can help to reduce risk and improve the outcome (Kooskora and Meel 2003). Collins (2012) presented some beneficial best practices that can decrease the ethical risk and improve performance. He included the following activities: hiring ethical people, codes of ethics, ethical decisionmaking frameworks, ethics training, ethics systems for reporting, ethical leadership, clear work goals and appraisals, empowering ethical employees, and environmental management. Therefore, we can state that ethical behavior can limit potential ethical risks.

Corporate codes of conduct become practical instruments used to manage employee behavior and establish responsible organizational culture (Erwin 2011). Formal codes of ethics are given various titles, including codes of ethics, codes of conduct, and operating principles (Cassell et al. 1997). Regardless of their name, they have a similar purpose-to be coherent with the ethical principles and practices valued by the company. However, they should not be based just on the ethical responsibility of company (Carasco and Singh 2003). They can demonstrate and emphasize the top management's commitment for ethics and help improve a favorable ethical climate and culture (Koh and Boo 2004). Preferably, codes of ethics affect the organizational culture by governing the actions and conduct of 
employees through the promotion of ethical business practices, which at the same time help them to avoid possible legal consequences (Matten 2003). Codes of ethics enhance corporate reputation and brand image, convey the message that the corporation is committed to ethical behavior; they could rally employees around a corporate culture, lead to reduced penalties, and enhance development prospects in emerging economies (Singh et al. 2005). Additional benefits may include product differentiation, risk management and reduced insurance premiums, reduced negative consumer actions (e.g., boycotts), and improved customer relations (Lenox and Nash 2003). In addition to all this, it must be mentioned that a code of ethics is more than a set of rules about good and bad behavior; it serves as an outline of expected professional performance, core values, and standards that ensure safety for the public (Russell 2019). If no ethics are implemented, stakeholders and the business organization itself will be affected. In addition, when unethical practice occurs, the organization's reputation and good image will be strongly damaged (Jalil et al. 2010), which leads to the restraint of negative consequences as, for example, the loss of customers or investors. The importance of such documents in the organizational practice is reflected by the fact that not just managers are engaged in its creation. Incorporation of ethics programs-connected actions and responsibilities related with ethics in companies are still particularly done at the board level (Dondé 2020).

Conrad (1993) noted that companies use discourse to instill their core values and ethical codes. However, Canary and Jennings (2008) argued that code content is likely to reflect the ways of thinking of those designing the code rather than the organization. According to Wotruba et al. (2001), codes of ethics can serve three major purposes in organizations: demonstrating their concern for ethics, transmitting their ethical values to its members, and impacting the ethical behavior of those members. Weaver (1993) added that the demonstration of an apprehension for ethics is the essential drive for establishing a code of ethics in many organizations. Regardless of the nature of the design process, or its content, a code of ethics might be an attempt to purposively influence, or control, the ethical dimensions of members' behavior (Adam and Rachman-Moore 2004), which is particularly difficult in companies which operate in more than one country or cultural region. In such corporations, ethical codes can help govern operations worldwide and promote uniformity (Carasco and Singh 2003). In their implementation process, companies use formal methods such as: training, courses and means of enforcement, which are common and suitable for selfregulation, but at the same time investment-intensive (Adam and Rachman-Moore 2004).

In research, the existence of a code of ethics in the company relates to performance, but social and environmental performance especially. As an example, Cuadrado-Ballesteros et al. (2017) examined the mediation effect of ethical codes on the relationship between family ownership and the degree to which the management achieves a strong social and environmental performance. Their study was not aimed at the extent of the code, but the advance of its processing. We believe that companies consider the code of conduct as a nonfinancial tool for increasing stakeholder satisfaction, and therefore it should be linked with social and environmental levels of corporate performance. Thus, there is no necessity to link ethics and financial performance, even though as stated by Virakul et al. (2009), among the main motives for promoting socially responsible practices, it is necessary to note economically driven motivations.

Recently, the problem of ethics has been addressed by the scientific community, especially in connection with education, medicine, and research. Worldwide, the role and implementation of ethical codes are have been examined in healthcare research (medicine, nursing, and pharmacy), but these studies (Bah and Sey-Sawo 2018; Roche 2019; Borysowski et al. 2020; Pan and Ruble 2020; Young 2020) focused on the desired changes in the behavior of individuals or groups, they do not deal with factors affecting the code itself. In fact, the even managerial research does not focus on the issue of business ethics itself but is directed towards advanced specific issues such as the possibility of changing the ethical direction of the business sector trough building pro-social behavior (Konow 2019), the role of local initiatives in creating community cohesiveness in social 
change efforts (Parsons et al. 2020) or influence firms' practices (Guo et al. 2020). Therefore, our study is unique in its narrow focus on main factors that influence extent of the ethical codes not just in the conditions of multinational companies operating in Slovakia. These factors as ownership, number of employees and area on which the ethical code primarily focus are not included in such specific form and connection in any previous research, which can be emphasized as a huge research gap that our study fills overall. One of the rare studies was conducted by Lee et al. (2014), who examined ethics and corporate philanthropy and included only two related variables as antecedents, and turnover intention as a consequence of job and organizational engagement. In addition, in Slovakia there is no primary research in the field of business ethics at all. Despite the fact that several (especially multinational) companies operating in the Slovak Republic have adopted some form of code of ethics, the public still has little knowledge in the topic. Single-study mapping of this issue in Central Europe was conducted by Sroka and Lőrinczy (2015) on 200 companies from the V4 countries. Their results confirmed that business ethics is considered a key factor that has an impact on the success and profits of modern companies in V4, and it is assumed that its role will increase in the future.

Our study focused on the identification of factors that influence the extent of the ethical code in the multinationals operating in Slovakia. The reason is very simple. As companies become more multinational, the need for ethical code is more relevant as stated in Kaptein (2004), and to date, no research has been conducted to examine the extent of ethical code in multinational companies according to selected factors. According to extent, several types of ethical code (Langlois and Schlegelmilch 1990) should be usually found in companies: (1) regulatory documents giving specific advice on behavior (associated with norms and rules to standardize business procedures); (2) short, broad principles of aim and values (list, where do's and don'ts are clearly explained; (3) elaborate codes including social responsibility (in big companies, where principles and standards dictate how companies may work and behave) After describing the research sample and variables, the methodological procedure of research and the sequence of used mathematical-statistical methods by which the established hypotheses were verified, was presented. Flowingly, the main results and their confrontation with the results of other authors took place in the discussion. The conclusion offers the main results, their limitations, and ways and possibilities to expand existing research and complete the theoretical basis as well as knowledge from business practice in this area.

\section{Materials and Methods}

The main goal of this study was to identify factors that influence the extent of the ethical code in the conditions of companies operating in Slovakia. Therefore, the following methodology was designed. The research was conducted in the time period of July 2019 to September 2020. In the initial phase, the selection of methods and research sample took place. In August and September 2020, the pilot study was conducted on the sample of 10 companies. A pilot study was carried out in the form of semi-structured interviews (DiCicco-Bloom and Crabtree 2006; Qu and Dumay 2011) led in face-to face form (Opdenakker 2006) as the qualitative research interview (Hollway and Jefferson 2000; Gubrium and Holstein 2001). In this pilot study, 10 representatives of preselected companies responded to the prepared set of open-ended questions (Pulakos and Schmitt 1995; Turner 2010). These companies were already involved in our previous research, and their representatives were willing to give us feedback on the composition of the questions and the course of the interview. Based on their comments, we did not include questions about the impacts and effects of the incorporation of the code of ethics on selected managerial processes in the research, because the respondents were not willing to answer questions of this type. Also, the pilot study of this research indicated that using a trained interviewer (who conducted an interview with the representative of the monitored company) brings more relevant results (compared to the situation where the subject is directly addressed for participation in the research but contributes in it by filling in a questionnaire form sent by 
e-mail, which he processes on his/her own). Based on the results of the pilot research (Van Teijlingen and Hundley 2001), a questionnaire was compiled, and in the third phase of the research was addressed to subsidiaries of multinational companies operating in Slovakia.

In the end, the research was conducted in the form of an interview (Gillham 2000) using the Google online questionnaire (Rayhan et al. 2013) filled out by the group of trained interviewers. The data collection was conducted by trained interviewers who were acquainted in advance with the content of the questionnaire and the terms included in it. Since the field of business ethics is difficult to master the terminology, the interviewers completed the theoretical preparation in the initial phase of the research.

The design of the questionnaire can be seen in Table 1, as well as the method of collection of data, which were collected as ordinal data. By reducing detailed measures to a sequence of ordinal numbers, rankings make it possible to evaluate complex information according to certain criteria (Malara et al. 2016).

Table 1. Design of questionnaire: operationalization of variables.

\begin{tabular}{|c|c|c|c|}
\hline Coding & Variables & Operationalization & Measurement \\
\hline PSA & $\begin{array}{l}\text { Primary specific area of } \\
\text { Ethical code }\end{array}$ & $\begin{array}{l}\text { What specific area does the } \\
\text { Ethical code primarily focus on? }\end{array}$ & $\begin{array}{l}\text { 1- General rejection of unethical practices, } \\
\text { 2- Corruption, 3- Personnel problems, 4- Cultural } \\
\text { differences, 5- Marketing problems, 6- Relations } \\
\text { with governments and state institutions, 7- Other }\end{array}$ \\
\hline EXT & Extent of Ethical code & $\begin{array}{l}\text { What is the extent of the Ethical } \\
\text { code? }\end{array}$ & $\begin{array}{l}\text { 1- (0-5 pages), } 2-(6-10 \text { pages }), 3-(11-20 \text { pages }), \\
4-(21-50 \text { pages }), 5-(51-100 \text { pages }), 6 \text { - (more than } \\
100 \text { pages })\end{array}$ \\
\hline PAT & Economic performance & What is your profit after tax? & Profit after tax according to balance sheet \\
\hline EMP & Size of the company & $\begin{array}{l}\text { How many employees work in } \\
\text { the company? }\end{array}$ & $\begin{array}{l}\text { 1- 0-9 (micro-enterprise) 2- 10-49 (small } \\
\text { enterprise), 3- 50-249 (medium enterprise), 4- } 250 \\
\text { and more (large enterprise) }\end{array}$ \\
\hline REG & $\begin{array}{l}\text { Regional scope of the } \\
\text { company }\end{array}$ & $\begin{array}{l}\text { Which regions does the company } \\
\text { operate in, in the Slovak } \\
\text { Republic? }\end{array}$ & $\begin{array}{l}\text { 1- activity only in the region of the seat (only } 1 \\
\text { region), 2- activity in several regions, but not in all, } \\
\text { 3- activity in all regions }\end{array}$ \\
\hline IND & Industry & $\begin{array}{l}\text { Which industry you operate in as } \\
\text { a core business? }\end{array}$ & $\begin{array}{l}\text { 1- Automobile industry, 2- Services, 3- Other } \\
\text { engineering industry, 4- Chemical industry, } \\
\text { 5- Food industry, 6- Textile and clothing industry, } \\
\text { 7- Wood processing industry, 8- Construction, } \\
\text { 9- Agriculture, 10- Forestry, 11- Purchase and } \\
\text { trade, 12- transportation, 13- Metallurgy, } \\
\text { 14- Hospitality (accommodation and catering), } \\
\text { 15- Insurance, banking, and finance }\end{array}$ \\
\hline AFF & Affiliates in Slovakia & $\begin{array}{l}\text { How many affiliates operate in } \\
\text { Slovakia? }\end{array}$ & Number of affiliates operating in Slovakia. \\
\hline OWN & Ownership structure & What is the ownership structure? & $\begin{array}{l}\text { 1- Exclusively Slovak, 2- Co-ownership of Slovak } \\
\text { and foreign, 3- Exclusively foreign }\end{array}$ \\
\hline EXD & $\begin{array}{l}\text { Executive director } \\
\text { nationality }\end{array}$ & $\begin{array}{l}\text { What is the nationality of the } \\
\text { executive director? }\end{array}$ & $\begin{array}{l}\text { 1- Nationality of the home country, 2- Slovak-A } \\
\text { member of the nationality of the host country, } \\
\text { 3- Two directors (one from the home-one from } \\
\text { the host country), } 4 \text { - Nationality of a third country }\end{array}$ \\
\hline
\end{tabular}

Source: own processing.

During the period of October 2019 to July 2020, the samples of 302 Slovak companies were addressed, which can be considered as multinational, out of which 250 companies cooperated in the research and answered the questions. Therefore, the response rate was $82.78 \%$. Subsequent modification of the data was made, in which incomplete and incorrect answers were excluded, and the sample was adjusted to the final number of 225 companies examined. 
In respect of limitations connected with COVID-19, most of these interventions were conducted in the form of an online interview through various applications (most often MS Teams and Zoom). Paradoxically, this situation had a positive effect on the research, because the representatives of the monitored companies were more willing to meet online than physically due to the time and administrative complexity of personal meetings (for a visit in the company, the interviewer usually needed specific entry permission, for a meeting outside of the company, the representative usually needed permission from his superior or human resources department).

For the purposes of the research, we used a stratified random selection based on the following criteria: the entity had to be a separate business unit with its own legal entity registered in the Slovak Commercial Register, and at the same time, the entity had to be connected to a foreign multinational company in some way. The existence of a relationship between the foreign parent company and the Slovak subsidiary was of key importance. The nature of this relationship could be various: the mother's complete ownership, the mother's partial capital participation, the sale of a license, franchising, etc. Attention was also paid to the person who represented the company at the interview. When approaching the cooperation, the purpose and form of the research were introduced and a request for the company to be represented by a director, manager, or another employee involved in ethical issues of the company was also made. The reason for this stratified randomization was low engagement of local companies in the formalization of ethics in the form of implementation of ethical code in the set of organizational documents and rules found in our previous research (Urbánová et al. 2020). The topic of organizational ethics and its formalization was introduced to the Slovak business sector by multinational companies which incorporated them a long time ago and dismissed this practice to countries with interrupted continuity of private business and its managerial practice by state arrangements before 1989 (Kozáková 2020). One of the main reasons is that large companies in both the U.S. and the EU have had to address issues of ethics and corporate culture due to the Federal Sentencing Guidelines (U.S.) and the EU's General Data Protection Regulation (Martínez et al. 2020). Moreover, in the system of capitalism which is pervasive among industrially advanced countries (because it satisfies the economic mission most efficiently and effectively), business ethics plays the essential role, because it makes the practice of capitalism more ethical. This approach was also used by (Cuadrado-Ballesteros et al. 2017), who conducted research on social performance, codes of ethics and family firms, using a panel dataset composed of 547 internationally listed companies exclusively. Our approach of examining the formalization of ethics in the conditions of a post-communist country is unique in its focus on national business entities with a connection to a foreign parent company. We believe that the examination of transfer of managerial tools to transit economies by multinational companies in the process of globalization allows us to form the basis for further scientific research of other market participants. Regarding this, we consider it appropriate to follow up in the future and address Slovak business entities connected to multinational companies in the supply chain (because local suppliers are pushed to adopt new management practices-including the implementation of the code of ethics-by their foreign-owned customers), and in the next phase we can address local entities without links to foreign companies. We believe that the study of neighborhood effects in the implementation of codes of ethics in Slovakia would also bring beneficial results.

With $95 \%$ of probability that the sample truthfully reflects the attitudes of the population and $7 \%$ margin of error, a sample of 225 can be considered as representative. Chosen variables for further testing were selected from the questionnaire (Table 1).

Cronbach's alpha was used to assess the reliability of the research. Kaiser-MeyerOlkin (KMO) measure of sampling adequacy (Williams et al. 2010) was applied to prove whether factor analysis was appropriate for analysis of the ethics coverage. According to this criterion, the data fit for application of factor analysis. Factor analysis (Lawley and Maxwell 1962) was made to identify the interdependencies between observed variables, 
to find the latent variables and to reduce the set of variables in a dataset and specially to identify those variables which correlate with the variables of ethics. Two factors with eigenvalues greater than one were selected and analyzed with Varimax Rotation Method (Forina et al. 1989). For clarity of the factor definitions, factor loadings of more than 0.4 were considered for further analysis. The assumptions of differences for these variables (knumber of samples (groups)) and hypotheses were set:

The Null Hypothesis 0 (H0). All k populations have the same distribution.

Alternative Hypothesis $\mathbf{1}$ (H1). The distribution of Extent of the Ethical code in Slovak multinational companies is different across category of specific area of the Ethical code.

Alternative Hypothesis 2 (H2). The distribution of Extent of the Ethical code in Slovak multinational companies is different across category of number of employees.

Alternative Hypothesis 3 (H3). The distribution of Extent of the Ethical code in Slovak multinational companies is different across category of Slovak/foreign ownership structure.

These hypotheses were statistically tested through the Kruskal-Wallis test (Ostertagova et al. 2014) to identify the differences among the variables using a statistical addition to excel-XL stat. The Kruskal-Wallis test (Kruskal and Wallis 1952) is a nonparametric approach to the one-way ANOVA (Van Hecke 2012). The Kruskal-Wallis test was used because the assumptions of one-way ANOVA were not met, and dependent variable was not normally distributed, and there was not approximately equal variance on the scores across groups. The procedure was used to compare three or more groups on a dependent variable that is measured on at least an ordinal level. One of the most important applications of the test is in detecting differences among the population means (Munk et al. 2010). As the computed $\mathrm{p}$-value is lower than the significance level alpha $=0.05$, one should reject the null hypothesis $\mathrm{H}_{0}$, and accept the alternative hypothesis $\mathrm{H}_{1}, \mathrm{H}_{2}, \mathrm{H}_{3}$.

As a post hoc test to the Kruskal-Wallis test, the Bonferroni correction test (Armstrong 2014) was included to counteract the problem of multiple comparisons between the examined variables. Bonferroni correction lowers the critical $P$ values for each particular test based on the number of tests to be performed and is frequently used to reduce problems associated with multiple comparisons (Cabin and Mitchell 2000).

\section{Results}

The original questionnaire contained 13 questions. The questionnaire was inspired by previous research of relevant scientists (Canary and Jennings 2008; Jalil et al. 2010; Twomey and Jennings 2011). Data adjustment was made after multiple testing to obtain reliable Cronbach's alpha (Brown 2002); therefore, the data were reduced to 9 analyzed variables. Variables that were also part of the beginning of the research as variables of legal form, occurrence of ethical scandals, home country of multinational company and form of entering the Slovak market were excluded from further analysis, since their influence on overall weak reliability was discovered throughout the statistical testing. For these variables, we can conclude that they are not significantly connected to the topic of the extent of the ethical code, and therefore, they are not further analyzed in this research. These results were surprising, especially in the case of legal form, which is usually identified as a significant factor in Slovak conditions (Fidrmuc and Hainz 2010; Tóth et al. 2014; Kravčáková Vozárová et al. 2019). Regarding this, we recommend using these variables in future studies.

Ownership structure of the analyzed companies shows that most of them (164 out of 225) have exclusively foreign ownership, and that, on the other side, the least of them (26 out of 225) have exclusively Slovak ownership. This can relate to the fact that mainly multinationals were approached for ethics formalization because of the presumption that not many typical Slovak companies (without international connections) have the ethical 
code, and if they have one, their extent will not be very long, which was also proved by our sample. Throughout the whole sample, the shortest extent is visible the most (68 altogether), followed by the extent with 11-20 pages, and 21-50 pages (Table 2). The longest extent of the ethical code is noticed mainly in the connection with the exclusively foreign ownership, which is the only group where the ethical code longer than 100 pages ( 2 companies) is included. These outcomes indicate that the managerial approach of companies varies depending on their ownership structure. If the foreign subsidiary is exclusively owned by the parent company, it is more practical to ensure the extension of the desired ethical standards by formalizing more detailed rules summarized in an extensive code of ethics. On the contrary, with the increasing Slovak ownership, it is easier for owners and managers to supervise the observance of ethical principles and standards directly, and it is therefore not necessary to formalize them in a long document. The Kaiser-Meyer-Olkin measure of sampling adequacy showed that data suited for Factor Analysis. Analyzed variables resulted as mediocre, with the range between 0.5 and 0.7 (PSA: 0.664; PAT: 0.675; REG: 0.642.; EXD: 0.620) and as good (EXT: 0.794; EMP: 0.702; IND: 0.761; AFF: 0.738; OWN: 0.721 ), with the values between 0.7 and 0.8 . Calculated Cronbach's alpha coefficient of 0.799 indicates high level of internal consistency, and therefore a high reliability of the data set.

Table 2. Structure of the sample's extent of ethical code.

\begin{tabular}{cc}
\hline Extent of Ethical Code & Number of Subjects \\
\hline$(0-5$ pages $)$ & 68 \\
\hline$(6-10$ pages $)$ & 37 \\
\hline$(11-20$ pages $)$ & 52 \\
\hline$(21-50$ pages $)$ & 46 \\
\hline$(51-100$ pages $)$ & 20 \\
\hline (more than 100 pages) & 2 \\
\hline Sum of all the subjects: & 225 \\
\hline Source: own processing.
\end{tabular}

As designed in Table 3, the first factor explains over $25 \%$ and the second factor explains almost $21 \%$ of the variance. The percentage of variance to determine the amount of variance that these two factors explain is $46 \%$, which means there are some additional variables explaining the overall variance.

Table 3. Percentage of variance after Varimax rotation.

\begin{tabular}{ccc}
\hline & F1 & F2 \\
\hline Variability (\%) & 25.395 & 20.995 \\
Cumulative (\%) & 25.395 & 46.390 \\
\hline
\end{tabular}

Source: own processing.

After the Varimax rotation seen in Table 4, two main factors and the correlations between variables and factors were identified. Factor one recognized as area of operation includes regions, industry, and number of affiliations variables with the values more than 0.4. These results indicate that these three variables have no relationship with ethics. This means that the area in which the company operates, and number of its affiliates, has no connections with the decisions about the ethical code and its extent.

For the purpose of the article which deals with ethics, Factor 1 was not selected for further analysis, since here the variables of ethics were not significant.

Factor number two was identified as ethics coverage, and the variables of more than 0.4 were considered as significant and used for further analysis of the relationships between them. Kruskal-Wallis test was used to verify the hypothesis that the distribution of (EXT) 
Extent of the Ethical code is different across categories of 1 ; Specific area of the Ethical code (PSA); 2. Number of employees (EMP); 3. Slovak/foreign ownership structure (OWN).

Table 4. Correlations between variables and factors after Varimax rotation.

\begin{tabular}{ccc}
\hline Variables & F1 & F2 \\
\hline PSA & 0.026 & -0.680 \\
EXT & 0.038 & 0.635 \\
PAT & 0.313 & 0.248 \\
EMP & 0.137 & 0.627 \\
REG & 0.661 & -0.076 \\
IND & 0.765 & -0.158 \\
AFF & 0.865 & 0.236 \\
OWN & -0.042 & 0.524 \\
EXD & 0.109 & 0.125 \\
\hline
\end{tabular}

Source: own processing.

For all the set hypotheses, null hypothesis was rejected; therefore, all of them were confirmed as significant. Ties have been detected in the data and the appropriate corrections have been applied by the Bonferroni correction post hoc test. From the selected hypotheses, hypothesis H1 was the most significant (Table 5), which was expected, while they both determine the overall code of ethics; however, from the different perspectives. The risk to reject the null hypothesis $\mathrm{H} 0$, while it is true, is lower than $0.01 \%$.

Table 5. Kruskal-Wallis test according to the extent of the ethics code.

\begin{tabular}{cc}
\hline Variable $\backslash$ Test & $p$-Value \\
\hline PSA & $<0.0001$ \\
EMP & 0.012 \\
OWN & 0.017 \\
\hline
\end{tabular}

Source: own processing.

Table 6 shows significant difference between the shortest extent of ethical code and others, except the longest one. Between the shortest range of ethical code and other lengths are differences, except the longest one. It is logical, when a company chooses to have a noticeably short code of ethics ( $0-5$ pages), it will be very general, and the length does not allow for focusing on specific ethics problems or area. If a company wants to focus on any specific area in code, higher extent is needed.

Table 6. $p$-Values of specific area on which the ethical code primarily focuses on and extent of the ethical code after Bonferroni-corrected significance level: 0.0033.

\begin{tabular}{|c|c|c|c|c|c|c|}
\hline PSA. & PSA | 1 & PSA | 4 & PSA I 5 & PSA I 3 & PSA | 2 & PSA I 6 \\
\hline PSA I 1 & 1 & $<0.0001$ & 0 & $<0.0001$ & $<0.0001$ & 0.049 \\
\hline PSA $\mid 4$ & $<0.0001$ & 1 & 0.826 & 0.465 & 0.769 & 0.476 \\
\hline PSA I 5 & 0 & 0.826 & 1 & 0.432 & 0.655 & 0.539 \\
\hline PSA I 3 & $<0.0001$ & 0.465 & 0.432 & 1 & 0.7 & 0.358 \\
\hline PSA 12 & $<0.0001$ & 0.769 & 0.655 & 0.7 & 1 & 0.424 \\
\hline PSA I 6 & 0.049 & 0.476 & 0.539 & 0.358 & 0.424 & 1 \\
\hline
\end{tabular}

Source: own processing.

The variable of number of employees impacts the extent of the ethics code through the managerial approach, which must be different in case of different numbers of employees. This strongly effects formalization of ethics. Ties have been detected between the number of employees (Table 7) for the extent of the ethics (6-10) and the second longest extent of the ethics (51-100). With a lower number of employee, a company does not have to conduct strong ethical rules and thus does not need the extensive ethical code. On the other hand, 
in large companies with many employees, direct transfer of the ethical requirements is almost impossible, while it demands direct contact of the manager and their subordinates.

Table 7. $p$-Values between number of employees and extent of the ethical code after Bonferronicorrected significance level: 0.0033 .

\begin{tabular}{ccccccc}
\hline EMP & EMP | & EMP | 4 & EMP | 5 & EMP |3 & EMP | & EMP | 6 \\
\hline EMP | 1 & 1 & 0.044 & 0.005 & 0.264 & 0.418 & 0.676 \\
EMP | 4 & 0.044 & 1 & 0.219 & 0.375 & 0.013 & 0.343 \\
EMP | 5 & 0.005 & 0.219 & 1 & 0.053 & 0.002 & 0.171 \\
EMP | 3 & 0.264 & 0.375 & 0.053 & 1 & 0.084 & 0.483 \\
EMP | 2 & 0.418 & 0.013 & 0.002 & 0.084 & 1 & 0.853 \\
EMP | 6 & 0.676 & 0.343 & 0.171 & 0.483 & 0.853 & 1 \\
\hline
\end{tabular}

Source: own processing.

From Table 8 of pairwise differences, ties have been detected between the Slovak/foreign ownership structure of the shortest extent of the ethics ( $0-5$ pages) and the second one (extent of 5-10 pages). The ownership structure in the form of the foreign capital impacts the creation and the extent of the ethics code, which can be explained by the managerial consequences of the inclusion of foreign capital in the company. Foreign ownership has an impact not only on financial means but also on managerial aspects. An accompanying phenomenon is the transformation of knowledge and managerial approaches which are usually visible in the strategy of formalizations of ethics, by creation and the extent of the ethics code.

Table 8. $p$-Values between ownership and extent of the ethical code after Bonferroni-corrected significance level: 0.0033 .

\begin{tabular}{ccccccc}
\hline OWN & OWN I 1 & OWN I4 & OWN I & OWN I3 & OWN I 2 & OWN I6 \\
\hline OWN I 1 & 1 & 0.017 & 0.014 & 0.035 & 0.003 & 0.186 \\
OWN I 4 & 0.017 & 1 & 0.523 & 0.75 & 0.466 & 0.493 \\
OWN I5 & 0.014 & 0.523 & 1 & 0.371 & 0.971 & 0.662 \\
OWN I3 & 0.035 & 0.75 & 0.371 & 1 & 0.295 & 0.437 \\
OWN I 2 & 0.003 & 0.466 & 0.971 & 0.295 & 1 & 0.645 \\
OWN I6 & 0.186 & 0.493 & 0.662 & 0.437 & 0.645 & 1 \\
\hline
\end{tabular}

Source: own processing.

\section{Discussion}

Codes of conducts are documents which vary in length, breadth of topics covered, and extent to which topics are covered (Singh et al. 2005). The extent and length of ethical code do not necessary mirror its quality, nor effectiveness. More important is philosophy and values of management that are usually performed in ethical codes (Kaptein 2004). There are several factors that influence business performance more than ethical code. For example, personal relationships can increase economic performance much more than ethical code (Lovett et al. 1999). On the other side, ethical code is important for sustainable success and it is a factor reducing business risk (Samedova 2010). Therefore, an assessment of extent of code is just one aspect to evaluate overall view on ethical code. Our findings show a significant difference just between a noticeably short document ( $0-5$ pages) and 4 other lengths (2- (6-10 pages); 3- (11-20 pages); 4- (21-50 pages); 5- (50-100)), even though we stratified a company's ethical codes into 6 categories according to its length. Statistical difference was found between the shortest one and others. Less than five pages' ethical codes are general documents in which companies usually define themselves in relation to unethical practices generally and express their commitment to rationalize the company's activities in relation to all stakeholders in accordance with laws and ethical principles. The length of these documents does not allow them to engage in specific unethical activities or to concretize desired behavior in specific situations. This is against the short and less-specific codes detriment, the results of Holtzhausen (2015), who cuts out that people adhere to the 
rules or laws as set out by the group or society, rather than their moral impulse, because of their moral and physical poverty, misery, and misrecognition. However, the small extent and general focus do not detract from the quality of code. Erwin (2011 highlighted that codes of conduct have positive impacts despite their content, and codes of conduct are not a prerequisite for ethical conduct within organizations. His outcomes also support Adams et al. (2001), who stated that the sole act of establishing a formal code of conduct, regardless of content, is sufficient to impact perceptions of ethical behavior within organizations. These results also sustain our second outcome, that the number of employees impacts the extent of the ethical code. With the lower number of employees, an organization does not have to conduct strong ethical rules and thus does not need the extensive ethical code. On the other hand, this extent is influenced by the involvement of foreign shareholders in the ownership structure. The third important outcome of our study is that foreign capital that the parent company invests in the Slovak branch also brings managerial approaches which influence the creation and the extent of the ethics code. We consider these outcomes as positive, since Trevino et al. (1999) also detected that codes are not effective when used as strong control systems or for legal compliance, since this specific focus places them outside the climate and culture boundaries where employees feel ownership. The outcomes show importance of the scope of ethical codes and how the length can be smartly used for specific purposes of multinational companies. Since managing across borders and cultures is exceedingly difficult, the code of conduct can be used as a smart tool for extension of specific requirements across all subsidiaries in different countries in a non-directive and sophisticated fashion. This creates a base for further research aimed at two follow-up problems. The first one is quality of the codes content, its measurement, and factors. The second is effectiveness of their incorporation into a company's set of rules or tools for regulating employee behavior. In this research, however, it will be necessary to consider the characteristics of the cultures studied in the intentions as was laid by Hofstede (Hofstede 2011; Minkov and Hofstede 2011; Minkov and Hofstede 2014), since his dimensions can explain a lot of its results. For example, Singh (2011) concluded that when the corporate uncertainty avoidance increases, then consequently, the degree of code prescription and the intensity of codification may also increase, which reflects corporate propensity to uncertainty avoidance in corporate codes of ethics in different national cultures. Regarding these outcomes, we recommend for companies to incorporate ethical codes of length and extent suitable for their situation, which is determined mainly by their ownership structure and number of employees. Creating unreasonably long and detailed documents would be unnecessarily expensive for companies, and the effect of such inappropriately incorporated documents is also questionable. For example, Knoppers et al. (2011) proposed a code of conduct that incorporates seven principles (quality, accessibility, responsibility, security, transparency, accountability, and integrity), among which the length or extent is not included. Indeed, a balance of "value commitment" and the "space" needed for innovation is hard to establish (yet it is crucial for the success of a company and an integral part of organizational values) (Schnebel and Bienert 2004). Our results also indicate the need of boosting a prosocial approach in Slovak companies, which can be achieved by a systematic approach in education (mainly university education of economics and business students / future managers) focused on moral duty instructions, ethical behavior, social responsibility, and other prosocial concerns such as introduce Konow (2019). This recommendation is also in the line with the postmodern perspective of morality, which even goes further and rejects universal codes of ethics with many ethical rules or dogmas and places the burden of ethical decision-making solely on the individual (Holtzhausen 2015).

The slender focus of our research on variables that affect the ethical codes of companies in Slovakia has certain shortcomings in explaining the broader context and therefore creates some limitations. First, our factors explain the variance just partly (46\%), which means there are some additional variables explaining the overall variance, which gives the research 
additional possibilities to expand and complete the theoretical basis as well as knowledge from business practice in this area.

Research deals with the areas in which the ethical codes of examined companies are formally focused but does not deal with their motives for making specific ethical commitments. A similar approach of investigating explicit expressions of the codes of ethics, rather than implicit ethical values, was used also by Lee et al. (2014). Therefore, our study does not provide an answer to the extent to which companies introduce codes of ethics as tools for regulating employee behavior, although they may indicate such intentions. Our study is also unique in its connection of code of ethics with the multinational companies, because, in transforming economies where experience of independent entrepreneurship is historically absent, the incorporation of codes of ethics was introduced by multinational companies. These brought several previously unknown management practices and began to implement them in their subsidiaries, later suppliers and connected entities and indirectly to other market players too. For further research in the Slovak conditions, we would recommend methodically expanding the research by a qualitative approach and describing in more detail the reasons for the incorporation of ethical codes in the examined multinational companies (as, for example, Sadri et al. 1998; Velasquez and Velazquez 2002; Velasquez 2011) and provide abundance of examples, detailed real-life cases and answers as to whether the ethical issue faced by the company has necessitated the incorporation or amendment of a company code of ethics. Also, future research must respect Singh et al. (2005), who recommended the application of codes of ethics in emerging economies and establishment of cross-cultural standards.

Finally, the lack of research aimed at the business ethics in the Slovak conditions has also created a significant gap in the study of related areas and ethical issues in business. We identified shortcomings in the description of the connection between ethics and social responsibility in the Slovak conditions, while in the world the topic is under considerable attention (Epstein 1987; Singhapakdi et al. 1994; Singhapakdi et al. 2001; Singh and Singh 2013; Sharma 2017; Jiang et al. 2019). As a second important connection of ethics in practice of companies, we consider business outcomes which can be together incorporated under the topic of business excellence. As stated by (van der Merwe et al. 2003): "Where excellence exists, so also does ethics". For future research, we suggest using the approach of Peters and Waterman, who, back in 1982, established the basic criteria for corporate excellence several of which are concerned business ethics, with the possibility of enlarging their outcomes of the importance and the advantages brought by corporate social responsibility and intellectual capital when it comes to enhancing profit, productivity, and performance (Popescu and Popescu 2019). Very essential also would be to incorporate outcomes of Bui et al. (2020) to research aimed at business ethics. The author identified the knowledge gaps of sustainable corporate finance ((1) corporate finance in sustainability; (2) sustainable competitive advantages; (3) sustainable stakeholder engagement; (4) circular economy; (5) sustainable corporate finance innovation and risk management; and (6) sustainable supply chain ethics)). We believe that these can be considered also as ethical issues and would be needed to study ways and possibilities of their incorporation into a company's ethical codes, since these should provide values and standards regarding ensuring safety for the public (Russell 2019). Our last suggestion is based on the results of Valentine and Fleischman (2002), who highlighted that employees of entities that had an ethics code were more tolerant of societal diversity than the ones from companies without such document incorporated. We recommend verification of this outcome in the conditions of the Slovak transition economy, with the respect of already realized studies of diversity management (Eger et al. 2012; Egerová et al. 2013; Lančarič et al. 2015; Musa et al. 2017).

\section{Conclusions}

The goal of this study was to identify the main factors that influence the extent of the ethical code in the conditions of multinational companies operating in Slovakia. The study took steps in bridging the research gap by connecting formalization of ethics through 
ethical codes in the conditions of a transition economy of Slovakia where a significant role in this process took multinational companies. The study highlighted a lack of literature in this area with a complete absence in the Slovak conditions. Consequently, work offers an opportunity to develop theory and make practical recommendations for implementation.

We used the procedure of Factor analysis to identify two main factors: (1) area of operation (which includes regions, industry, and number of affiliates in which multinationals operates in) resulted as not correlated with ethics and (2) ethics coverage (which includes (PSA) specific area of ethical code, (EXT) extent of the ethical code, (EMP) number of employees and (OWN) Slovak/foreign ownership structure) considered in three main significances (Figure 1).

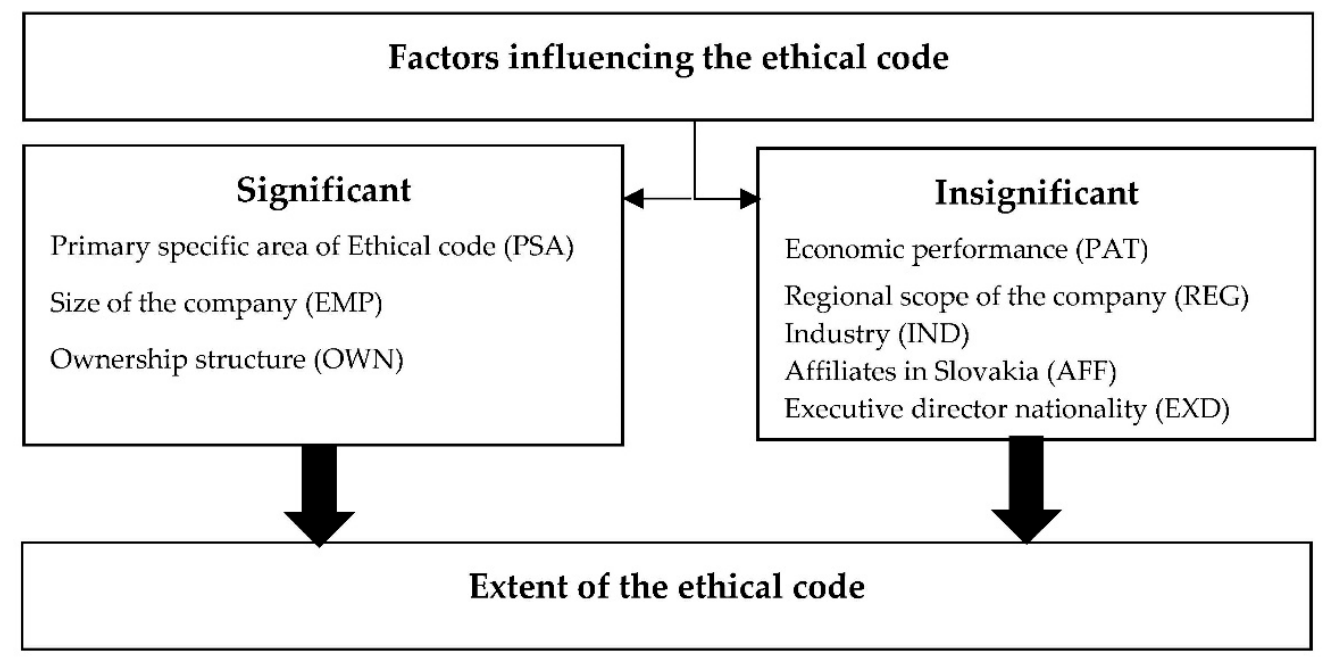

Figure 1. Factors that influence extent of the ethical code (Graphical conclusion). Source: own processing.

Factor analysis was followed by Kruskal-Wallis test to identify the differences among the variables and the Bonferroni correction test, which specified the items between which the significant difference occurred. The shortest examined extent of the ethical code (1-5 pages) is different from others and is essential to use in situations when a company wants generally to reject unethical practices and does not want/need to define employees' undesirable behavior defectively. Only sometimes this kind of ethical code includes issues connected with corruption, personnel problems, and cultural differences. Almost never marketing problems and relations with government occurred. Short ethical code has usually only formal function (where general phrases are used) to show publicly that a company is dealing with the issue connecting to ethical rules, and therefore it should be visible and perceived as an ethical organization. The difference was found between different-sized companies as well. It is because of different managerial approaches in the organizations. Micro and small enterprises usually use a directive way as to how to spread ethical standards, but in large enterprises it is impossible to do it this way. Therefore, large companies have a longer formalized ethical code where all areas including corruption, personnel problems, cultural differences, marketing problems, and relationship with state institutions are presented in a complex way. There is also a difference among organizations with Slovak, foreign, and mixed ownership, because foreign capital is obvious also in the ideas of the enterprises. The research shows that in Slovakia it is still mostly large companies and mostly companies with foreign ownership that incorporate longer ethical codes. We can even conclude that, the less foreign property there is in a company, the shorter the code of ethics it incorporates. We believe the reason is that companies in which Slovak owners have a larger share are prerequisites for the local owner to directly supervise compliance with ethical principles and principles and it is therefore not necessary to formalize them in a long, complex and detailed codes of ethics. Despite this, the recommendations rise for the Slovakian ownership multinationals to bear in mind also the 
number of employees and suppliers, while creating the ethical codes. By longer code, it is possible to cover more topics and explain desired behavior in more detail, which can help to eliminate possible ambiguities or misunderstandings, mainly in relation to suppliers or other external partners and thus gain a possibility of control over the behavior of their employees too. Indeed, the unethical behavior of partners can damage the reputation in the eyes of the public, just as if an ethical issue arose directly in the company (as did in case of Apple, which was criticized globally for ethical scandals in their supplier Foxcon).

Multinationals with foreign and mixed ownership has more experience with cultural differences and therefore principles of diversity management are highlighted in ethical codes in a wider perspective. In these enterprises, higher emphasis is placed on managing personnel problems as well, because they realized the vital role of human resources in the organizations. On the other hand, exclusively Slovak-owned companies prefer to present the issues connected with corruption and relationships with state institutions because they were significant problems represented in society in the past but play a key role also nowadays. The research had two main limitations. Methodically, research was applied to the Slovak market, with the focus on business entities which are connected to a foreign parent company, e.g., multinationals regardless of other criteria or the nature of the relationship with the parent company. The samples of 225 companies were examined, but the factors explain the variance just partly. In terms of content, the focus is on the scope of the ethical codes. This study does not deal with the motives for making specific ethical commitments in ethical codes, the quality of their content and effectiveness of their incorporating into company's documentation, which can be included in further research.

Ethical codes are voluntary tools, and their application is influenced by corporate policy, management priorities, objectives, and financial possibilities. We recommend for companies to focus on core values expressed in ethical code. Impact of code should be increased by the following issues: regular feedback from external groups; update of ethical code according to actual conditions and requirements; higher availability of the code for employees and for external stakeholders; and clear presentation by management. These issues should help to increase the efficiency of the ethical code regardless of its extent.

The findings of this study will be used in the academic and commercial sphere as well. The outcomes will be provided to representatives of the monitored companies to encourage them to reconsider the extent of their code of ethics depending on the closeness of communication with employees of their desired ethical behavior in respect of the nature of their business and the degree of decision-making autonomy. The results will also be used in the teaching process of International management and entrepreneurship at several Slovak universities involved in the project KEGA 005SPU-4/2019. The findings of this research can also be useful for research studies to further their work on ethics, indicating the contribution and the valuable role of the concept in companies' social performance.

Author Contributions: Conceptualization, J.K.; methodology, M.U.; software, M.U.; validation, M.U. and R.S.; formal analysis, M.U. and R.S.; investigation, J.K. and M.U.; resources, J.K.; data curation, M.U. and J.K; writing—original draft preparation, J.K. and M.U.; writing—review and editing, J.K., M.U. and R.S.; visualization, M.U. and R.S.; supervision, J.K. and R.S.; project administration, J.K.; funding acquisition, J.K., and R.S. All authors have read and agreed to the published version of the manuscript.

Funding: This research was co-funded by the project KEGA "Theory and practice of the international management and entrepreneurship in multicultural environment" from The Ministry of Education, Science, Research, and Sport of the Slovak Republic. Project registration number KEGA 005SPU$4 / 2019$.

Acknowledgments: This research was supported by the project KEGA “Theory and practice of the international management and entrepreneurship in multicultural environment" from The Ministry of Education, Science, Research, and Sport of the Slovak Republic. Project registration number KEGA 005SPU-4/2019. 
Conflicts of Interest: The authors declare no conflict of interest. The funders had no role in the design of the study; in the collection, analyses, or interpretation of data; in the writing of the manuscript, or in the decision to publish the results.

\section{References}

Adam, Avshalom M., and Dalia Rachman-Moore. 2004. The methods used to implement an ethical code of conduct and employee attitudes. Journal of Business Ethics 54: 225-44. [CrossRef]

Adams, Janet S., Armen Tashchian, and Ted H. Shore. 2001. Codes of Ethics as Signals for Ethical Behavior. Journal of Business Ethics 29: 199-211. [CrossRef]

Armstrong, Richard A. 2014. When to use the Bonferroni correction. Ophthalmic and Physiological Optics 34: 502-8. [CrossRef] [PubMed]

Axelrod, Alan. 2004. My First Book of Business Ethics. Philadelphia: Quirk Books, p. 7.

Bah, Haddy Tunkara, and Jainaba Sey-Sawo. 2018. Teaching and practicing nursing code of ethics and values in the Gambia. International Journal of Africa nursing Sciences 9: 68-72. [CrossRef]

Bassell, Myles, Dov Fischer, and Hershey H. Friedman. 2015. The Importance of Business Ethics and Corporate Social Responsibility: A Course Module. Brooklyn: Brooklyn College, School of Business, 24p, SSRN 2646295. [CrossRef]

Borysowski, Jan, Hans-Jörg Ehni, and Andzej Górski. 2020. Ethics codes and medical decision making. Patient Education and Counseling, In press.

Brady, Neill F. 1999. A systematic approach to teaching ethics in business. Journal of Business Ethics 19: 309-18. [CrossRef]

Brown, James D. 2002. The Cronbach alpha reliability estimate. JALT Testing and Evaluation SIG Newsletter 6: 17-18.

Bui, Tad D., Mohd H. Ali, Feng M. Tsai, Mohammad Iranmanesh, Ming-Lang Tseng, and Ming K. Lim. 2020. Challenges and Trends in Sustainable Corporate Finance: A Bibliometric Systematic Review. Journal of Risk and Financial Management 13: 264. [CrossRef]

Cabin, Robert J., and Randall J. Mitchell. 2000. To Bonferroni or not to Bonferroni: When and how are the questions. Bulletin of the Ecological Society of America 81: 246-48.

Canary, Heather E., and Marianne M. Jennings. 2008. Principles and influence in codes of ethics: A centering resonance analysis comparing pre-and post-Sarbanes-Oxley codes of ethics. Journal of Business Ethics 80: 263-78. [CrossRef]

Carasco, Emily F., and Jamg B. Singh. 2003. The content and focus of the codes of ethics of the world's largest transnational corporations. Business and Society Review 108: 71-94. [CrossRef]

Cassell, Cathy, Phil Johnson, and Ken Smith. 1997. Opening the black box: Corporate codes of ethics in their organizational context. Journal of Business Ethics 16: 1077-93. [CrossRef]

Collins, Denis. 2012. Business Ethics: How to Design and Manage Ethical Organizations. Hoboken: Wiley, p. 592.

Conrad, Charles. 1993. The Ethical Nexus. Norwood: Ablex, ISBN 13: 978-0893918446.

Cuadrado-Ballesteros, Beatriz, Lázaro Rodríguez-Ariza, Isabel-María García-Sánchez, and Jennifer Martínez-Ferrero. 2017. The mediating effect of ethical codes on the link between family firms and their social performance. Long Range Planning 50: 756-65. [CrossRef]

Cullen, John B., Bart Victor, and Carrol Stephens. 1989. An ethical weather report: Assessing the organization's ethical climate. Organizational Dynamics 18: 50-62. [CrossRef]

De George, Richard T. 2005. A history of business ethics. In The Third Biennial Global Business Ethics Conference. Santa Clara: Markkula Center for Applied Ethics.

DiCicco-Bloom, Barbara, and Benjamin F. Crabtree. 2006. The qualitative research interview. Medical Education 40: 314-21. [CrossRef]

Dondé, Guendalina. 2020. Embedding Business Ethics: 2020 Report on Corporate Ethics Policies and Programmes. IBE 2020 Report on Business Ethics Policies and Programmes. IBE Organization. April. Available online: https:/ /www.ibe.org.uk/uploads/assets/ 0d2f6827-c3c7-43f3-91c104e7cd9470a1/IBE-Report-Embedding-Business-Ethics-Summary.pdf (accessed on 20 November 2020).

Duska, Ronald. 2000. Business ethics: Oxymoron or good business? Business Ethics Quarterly 10: 111-29. [CrossRef]

Eger, Ludvík, Dana Egerová, Milena Jiřincová, Jan Petrtyl, Miroslav Plevný, Miriam Bitterová, Drahoslav Lančarič, Andrej Peterka, and László Hajós. 2012. Diversity Management: Comparison, the Best Practices of Visegrad Countries. Plzeň: NAVA.

Egerová, Dana, Milena Jiřincová, Drahoslav Lančarič, and Radovan Savov. 2013. Applying the concept of diversity management in organizations in the Czech Republic and the Slovak Republic-A research survey. Technological and Economic Development of Economy 19: 350-66. [CrossRef]

Epstein, Edwin M. 1987. The corporate social policy process: Beyond business ethics, corporate social responsibility, and corporate social responsiveness. California Management Review 29: 99-114. [CrossRef]

Erwin, Patrick M. 2011. Corporate codes of conduct: The effects of code content and quality on ethical performance. Journal of Business Ethics 99: 535-48. [CrossRef]

Fidrmuc, Jarko, and Crista Hainz. 2010. Default rates in the loan market for SMEs: Evidence from Slovakia. Economic Systems 34: 133-47. [CrossRef]

Forina, Michelle, Ciril Armanino, Sergio Lanteri, and Riccardo Leardi. 1989. Methods of varimax rotation in factor analysis with applications in clinical and food chemistry. Journal of Chemometrics 3: 115-25. [CrossRef]

Freeman, Edward R. 2010. Strategic Management: A Stakeholder Approach. New York: Cambridge University Press, 268p, ISBN 98-0-52115174-0.

Gillham, Bill. 2000. Research Interview. New York: A\&C Black, British Library, 96p, ISBN 0-8264-4797-X-. 
Gubrium, Jaber F., and James A. Holstein. 2001. Forms of Interwieving Interviewing. In Handbook of Interview Research: Context and Method. Thousand Oaks: Sage Publications.

Guo, Ying, Lifang Wang, and Qian Yang. 2020. Do corporate environmental ethics influence firms' green practice? The mediating role of green innovation and the moderating role of personal ties. Journal of Cleaner Production 266: 122054. [CrossRef]

Van Hecke, Tanja. 2012. Power study of anova versus Kruskal-Wallis test. Journal of Statistics and Management Systems 15: 241-47. [CrossRef]

Koh, Hian Chye, and Elfred H. Y. Boo. 2004. Organizational ethics and employee satisfaction and commitment. Management Decision 42: 677-93.

Hofstede, Geert. 2011. Dimensionalizing cultures: The Hofstede model in context. Online Readings in Psychology and Culture 2. [CrossRef]

Hollway, Wendy, and Tony Jefferson. 2000. Doing Qualitative Research differently: Free Association, Narrative and the Interview Method. Hoboken: Sage.

Holtzhausen, Derina R. 2015. The unethical consequences of professional communication codes of ethics: A postmodern analysis of ethical decision-making in communication practice. Public Relations Review 41: 769-76. [CrossRef]

Jalil, Abdul, Ferdous Azam, and Muhammad K. Rahman. 2010. Implementation mechanism of ethics in business organizations. International Business Research 3: 145-55. [CrossRef]

Jiang, Ying, Xiaolong Xue, Chris K. Lo, and Hengquin Wu. 2019. Corporate Ethical Responsibility in Management Research: Intellectual Bases, Focus, Salience, and Future. Sustainability 11: 2368. [CrossRef]

Kaptein, Muel. 2004. Business codes of multinational firms: What do they say? Journal of Business Ethics 50: 13-31. [CrossRef]

Kelly, Emil P. 2002. Business ethics-An oxymoron? Forum on Business and Economics. Phi Kappa Phi Forum 82: 4-6.

Knoppers, Bartha M., Jennifer R. Harris, Anne M. Tassé, Isabelle Budin-Ljøsne, Jane Kaye, Miléne Deschênes, and H. Zawati Ma'n. 2011. Towards a data sharing Code of Conduct for international genomic research. Genome Medicine 3: 46. [CrossRef]

Konow, James. 2019. Can ethics instruction make economics students more pro-social? Journal of Economic Behavior E Organization 166: 724-34.

Kooskora, Mari, and Mari Meel. 2003. A Discussion of the Ethical Risks of Globalisation Globalization and Innovation. EBS Review 16: $5-7$.

Kozáková, Jana. 2020. Connection between Ethics and Diversity-Theoretical Study. In International Scientific Days 2020. Gödöllö: Szent István University, pp. 312-18. ISBN 978-963-269-918-9.

Kravčáková Vozárová, Ivana, Rastislav Kotulič, and Roman Vavrek. 2019. Disparities in the financial performance of agricultural entities according to the legal form: The case of Slovakia. Applied Economics 51: 5999-6008. [CrossRef]

Kruskal, William H., and W. Allen Wallis. 1952. Use of ranks in one-criterion variance analysis. Journal of American Statistic Association 47: 583-621. [CrossRef]

Lančarič, Drahoslav, Juraj Chebeň, and Radovan Savov. 2015. Factors influencing the implementation of diversity management in business organisationsorganizations in a transition economy. The case of Slovakia. Economic Research-Ekonomska Istraživanja 28: 1162-84. [CrossRef]

Langlois, Catherine, and Bodo Schlegelmilch. 1990. Do corporate codes of ethics reflect national character? Evidence from Europe and the United States. Journal of International Business Studies 21: 519-39. [CrossRef]

Lawley, David N., and Adam E. Maxwell. 1962. Factor analysis as a statistical method. Journal of the Royal Statistical Society. Series D 12: 209-29. [CrossRef]

Lee, Yong-Ki, Joowon Choi, Bo-young Moon, and Barry Jay Babin. 2014. Codes of ethics, corporate philanthropy, and employee responses. International Journal of Hospitality Management 39: 97-106. [CrossRef]

Lenox, Michael J., and Jennifer Nash. 2003. Industry self-regulation and adverse selection: A comparison across four trade association programs. Business Strategy and the Environment 12: 343-56. [CrossRef]

Lovett, Steve, Simmons Lee, and Kali Raja. 1999. Guanxi versus the market: Ethics and efficiency. Journal of International Business Studies 30: 231-47. [CrossRef]

Machan, Tibor R. 2009. Stakeholder Vs. Shareholder theory of ethics of corporate management. International Journal of Economics and Business Research 1: 12-20. [CrossRef]

Malara, Zbigniew, Rafal Miško, and Adam Sulich. 2016. Wroclaw university of Technology graduates career paths. Vesnik of Yanka Kupala State University of Grodno. Series 5. Economics Sociology Biology 6: 6-12.

Martin, K. Elly, and John B. Cullen. 2006. Continuities and extensions of ethical climate theory: A meta-analytic review. Journal of Business Ethics 69: 175-94. [CrossRef]

Martínez, Cecilia, Ann Greg Skeet, and Pedro M. Sasia. 2020. Managing organizational ethics: How ethics becomes pervasive within organizations. Business Horizons 64: 83-92. [CrossRef] [PubMed]

Matten, Dirk. 2003. Symbolic politics in environmental regulation: Corporate strategic responses. Business Strategy and the Environment 12: 215-26. [CrossRef]

Minkov, Michael, and Geert Hofstede. 2011. The evolution of Hofstede's doctrine. Cross Cultural Management. An International Journal 18: 10-20.

Minkov, Michael, and Geert Hofstede. 2014. A replication of Hofstede's uncertainty avoidance dimension across nationally representative samples from Europe. International Journal of Cross Cultural Management 14: 161-71. [CrossRef] 
Munk, Michal, Jozef Kapusta, and Peter Švec. 2010. Data preprocessing evaluation for web log mining: Reconstruction of activities of a web visitor. Procedia Computer Science 1: 2273-80. [CrossRef]

Musa, Hussam, Lenka Debnárová, Zdenka Musová, and Peter Krištofík. 2017. Gender equality and corporate governance in Slovakia. Economics and Management 20: 98-109. [CrossRef]

OECD. 1999. Codes of Corporate Conduct: An Inventory. Expanded Review of Their Contents. Organization of Economic Co-Operation and Development. Paris: Trade Directorate, p. 33.

Opdenakker, Raymond. 2006. Advantages and disadvantages of four interview techniques in qualitative research. Forum: Qualitative Social Research 7: 11.

Ostertagova, Eva, Oskar Ostertag, and Jozef Kováč. 2014. Methodology and application of the Kruskal-Wallis test. Applied Mechanics and Materials 611: 115-20. [CrossRef]

Pan, Raymond J., and James H. Ruble. 2020. A commentary on ethical decision-making in the pharmacy profession and the APhA Code of Ethics. Journal of the American Pharmacists Association. In press. [CrossRef] [PubMed]

Parsons, Elizabeth, Treasa Kearneyv, Emma Surman, Benedetta Cappellini, Sue Moffat, Vicky Harman, and Klara Scheurenbrand 2020. Who really cares? Introducing an 'Ethics of Care'toCare 'to debates on transformative value co-creation. Journal of Business Research 122: 794-804. [CrossRef]

Popescu, Cristina Raluca G., and Georghe N. Popescu. 2019. An exploratory study based on a questionnaire concerning green and sustainable finance, corporate social responsibility, and performance: Evidence from the Romanian business environment. Journal of Risk and Financial Management 12: 1-79.

Pulakos, Elaine D., and Neal Schmitt. 1995. Experience-based and situational interview questions: Studies of validity. Personnel Psychology 48: 289-308. [CrossRef]

Qu, Sandy Q., and John Dumay. 2011. The qualitative research interview. Qualitative Research in Accounting and management 8: 238-64. [CrossRef]

Rayhan, Rakib U., Yin Zheng, Ebsah Uddin, Christian Timbol, Oluwatoiyn Adewuyi, and James N. Baraniuk. 2013. Administer and collect medical questionnaires with Google documents: A simple, safe, and free system. Applied Medical Informatics 33: 12-21.

Roche, Cicely. 2019. Codes of Conduct/Ethics in Pharmacy Practice. Encyclopedia of Pharmacy Practice and Clinical Pharmacy 2019: 203-14.

Russell, Mary. 2019. Ethics and Civility: The Code We Live By. Journal of the Academy of Nutrition and Dietetics 119: 367. [CrossRef]

Sadri, Sorab, Sinha Arun, and Bonnerjee Peter. 1998. Business Ethics: Concepts and Cases. New York: Tata McGraw-Hill, p. 319.

Samedova, Ekaterina. 2010. Ethic code as a factor in reducing business risk. Journal of Russian Entrepreneurship 11: 25-30.

Schnebel, Eberhard, and Margo A. Bienert. 2004. Implementing ethics in business organizations. Journal of Business Ethics 53: 203-11. [CrossRef]

Schneider, Benjamin. 1975. Organizational climates: An essay. Personnel Psychology 28: 447-79. [CrossRef]

Sharma, Villiam K. 2017. Patient satisfaction and brand loyalty in healthcare organizations in India. Journal of Asia Business Studies 11: 73-87. [CrossRef]

Singh, Jang B. 2011. Determinants of the effectiveness of corporate codes of ethics: An empirical study. Journal of Business Ethics 101: 385-95. [CrossRef]

Singh, Tomba K., and Sanjoji M. Singh. 2013. Ethics in corporate social responsibility. IOSR Journal of Business and Management 9: 16-21. [CrossRef]

Singh, Jang, Emily Carasco, Goran Svensson, Greg Wood, and Michael Callaghan. 2005. A comparative study of the contents of corporate codes of ethics in Australia, Canada and Sweden. Journal of World Business 40: 91-109. [CrossRef]

Singhapakdi, Anusorn, Kenneth L. Kraft, Scott J. Vitell, and Kirk C. Rallapalli. 1994. The perceived importance of ethics and social responsibility on organizational effectiveness: A survey of marketers. Journal of the Academy of Marketing Science 23: 49-56. [CrossRef]

Singhapakdi, Anusoorn, Kiran Karande, C. P. Rao, and Scott J. Vitell. 2001. How important are ethics and social responsibility? A multinational study of marketing professionals. European Journal of Marketing 35: 133-53. [CrossRef]

Skripak, Stephen J. 2016. Ethics and Social Responsibility. In Fundamentals of Business. Blacksburg: Virginia Tech, pp. 56-80.

Sroka, Włodzimierz, and Marketa Lőrinczy. 2015. The perception of ethics in business: Analysis of research results. Procedia Economics and Finance 34: 156-63. [CrossRef]

Tóth, Marián, Drahoslav Lančarič, Andrea Piterková, and Radovan Savov. 2014. Systematic risk in Agriculture: A case of Slovakia. Agris On-line Papers in Economics and Informatics 6: 185-93.

Trevino, Linda, Gary Weaver, David Gibson, and Barbara L. Toffler. 1999. Managing Ethics and Legal Compliance: What Works and What Hurts. California Management Review 41: 131-51. [CrossRef]

Turner, Daniel W., III. 2010. Qualitative interview design: A practical guide for novice investigators. The Qualitative Report 15: 754-60.

Twomey, David P., and Marriane M. Jennings. 2011. Anderson's Business Law and the Legal Environment, 21st ed.Mason: SouthWestern Cengage Learning, p. 848.

Urbánová, Mária, Jana Kozáková, and Iveta Ubrežiová. 2020. The Code of Conduct in Slovak Slovak Companies. In International Scientific Days 2020. Gödöllö: Szent István University, pp. 360-70. ISBN 978-963-269-918-9.

Valentine, Sean, and Gary Fleischman. 2002. Ethics codes and professionals' tolerance of societal diversity. Journal of Business Ethics 40: 301-12. [CrossRef] 
van der Merwe, Rian, Leyland Pitt, and Pierre Berthon. 2003. Are excellent companies ethical? Evidence from an industrial setting. Corporate Reputation Review 5: 343-55. [CrossRef]

Van Teijlingen, Edwin R., and Vannora Hundley. 2001. The importance of pilot studies. Nursingstudies. Nursing Standard 16: 33-36. [CrossRef] [PubMed]

Van Tulder, Rob, and Ans Kolk. 2001. Multinationality and corporate ethics: Codes of conduct in the sporting goods industry. Journal of International Business Studies 32: 267-83. [CrossRef]

Velasquez, Manuel G. 2011. Business Ethics: Concepts \& Cases, 7th ed. International ed. Upper Saddle River: Pearsons, p. 496.

Velasquez, Manuel G., and Manuel Velazquez. 2002. Business Ethics: Concepts and Cases. Upper Saddle River: Prentice Hall, vol. 111, p. 420.

Victor, Bart, and John B. Cullen. 1988. The organizational bases of ethical work climates. Administrative Science Quarterly 33: 101-25. [CrossRef]

Virakul, Busaya, Kalayanee Koonmee, and Gary N. McLean. 2009. CSR activities in award-winning Thai companies. Social Responsibility Journal 5: 178-99. [CrossRef]

Weaver, Gary R. 1993. Corporate codes of ethics: Purpose, process and content issues. Business and Society 32: 44-58. [CrossRef]

Weinstein, Arnold. 2012. Superior Customer Value: Strategies for Winning and Retaining Customers. Boca Raton: CRC Press, p. 319.

Williams, Brett, Andris Onsman, and Ted Brown. 2010. Exploratory factor analysis: A five-step guide for novices. Australasian Journal of Paramedicine 8: 1-13. [CrossRef]

Wood, Greg. 2002. A partnership model of corporate ethics. Journal of Business Ethics 40: 61-73. [CrossRef]

Wotruba, Thomas R., Lawrence B. Chonko, and Therry W. Loe. 2001. The impact of ethics code familiarity on manager behavior. Journal of Business Ethics 33: 59-69. [CrossRef]

Young, Glendon. 2020. Toward a unified health work ethics code. Ethics, Medicine and Public Health 15: 100590. [CrossRef] 